\title{
Effect of Oral Clonidine on Hemodynamic Changes due to Laryngoscopy, Intubation and Operative Procedures Stress Response
}

\author{
Jehangir Allam ${ }^{1 *}$, Majid Mushtaq Sheikh ${ }^{2}$ and Roshan Ara ${ }^{1}$ \\ ${ }^{1}$ Kurji holy family hospital Patna Bihar, India \\ ${ }_{2}^{2}$ Malla Reddy Narayan Multispeciality Hospital, India
}

*Corresponding author: Jehangir Allam Bhat, Kurji holy family hospital Patna Bihar, India.

Received Date: October 27, 2018

Published Date: November 14, 2018

\begin{abstract}
Context: Endotracheal intubation constitutes a period of extreme hemodynamic stress. Clonidine, $\alpha 2$ adrenergic agonist, slows down the heart rate and leads to a dose-dependent decrease in systolic and diastolic blood pressure. It has $100 \%$ bioavailability following oral administration.

Aims: Effect of oral clonidine on hemodynamic changes due to laryngoscopy, intubation and operative procedures stress response.

Setting and design: This was a prospective, randomized controlled, double-blind study.

Materials and methods: Fifty patients of either sex, aged 18-45 years, ASA grade I/II undergoing elective surgeries under general anaesthesia were included. Group A received Clonidine $4 \mathrm{mcg} / \mathrm{kg}$ orally induction and group B received $5 \mathrm{ml}$ distilled water. Heart rate (HR), systolic blood pressure (SBP), diastolic blood pressure (DBP), mean arterial pressure, and rate pressure product were noted at baseline, reinduction, postinduction, intubation and thereafter, 1, 3,5,10,15,20,25 and 30min following intubation.

Results: There was a statistically significant difference in heart rate, systolic, diastolic, mean arterial pressure and rate pressure product between two groups. Clonidine group had more stable hemodynamic parameters throughout.

Conclusion: Oral clonidine premedication in the dose of $4 \mathrm{mcg} / \mathrm{kg}$ can effectively attenuate the hemodynamic stress response during laryngoscopy, intubation and operative procedures.
\end{abstract}

Keywords: Oral clonidine; Intubation; laryngoscopy; Pre-induction

\section{Introduction}

Induction of general anesthesia, direct laryngoscopy and endotracheal intubation induce marked cardiovascular changes as well as autonomic reflex activity [1]. Laryngoscopy with or without tracheal intubation amounts to a highly noxious stimulus to the homeostasis of the patient. Many a time under lighter planes of anesthesia it elicits a defense mechanism in the form of hemodynamic response to stress, which involves activation of adrenocortical system [2]. The response may be particularly hazardous for patients with cardiovascular and cerebrovascular diseases [3].
Hypertension, arrhythmias and myocardial ischemia induced by endotracheal intubation are the results of a reflex increase in sympathetic and sympathoadrenal activity [4]. Attenuation of these hemodynamic responses is of great importance in prevention of per operative morbidity and mortality. Strategies to circumvent these changes have included minimizing the duration of laryngoscopy, IV narcotics, IV and topical lignocaine, vasodilators, $\beta$-blockers, calcium channel blockers, inhaled an aesthetics and epidural analgesia. Although these drugs did obtund the cardiovascular response, they failed to fulfill the desired criteria of complete attenuation [5] 
Recently there has been considerable research in the $\alpha 2$ adrenergic agonist group of drugs in this respect. These drugs act at receptor site in medulla oblongata and presynaptically at peripheral nerve terminals, to cause a reduction in activity of sympathetic nervous system [6]. Clonidine, an imidazole compound is a selective agonist for $\alpha 2$ adrenoceptors with a ratio of 200:1( $\alpha 2: \alpha 1)$. Though primarily an antihypertensive, clonidine has been increasingly used for premedication [7,8]. Its central action reduces sympathetic activity, producing sedation, anxiolysis, dryness of secretions with reduction in requirement of anesthetic agents and improved cardiovascular stability in the perioperative period [9]. Clonidine premedication attenuates potentially harmful cardiovascular responses and hypertension during laryngoscopy and intubation [10]. Within the last decade, several studies have reported the successful use of oral clonidine premedication to prevent hyperadrenergic and hyperdynamic cardiovascular responses to endotracheal intubation $[11,12]$.

\section{Materials and Methods}

A prospective double-blind randomized control study was conducted after taking clearance from institutional ethical committee and proper consent. Patients who were ASA I and

Table 1: Demographic Profile.

\begin{tabular}{|c|c|c|c|c|c|c|}
\hline Parameters & \multicolumn{2}{|c|}{ Control Group A } & \multicolumn{2}{|c|}{ Oral Clonidine Group B } & Mean Deviation & P Valve \\
\hline \multirow{2}{*}{ Gender } & Male & 32 & Male & 40 & & \multirow{2}{*}{0.56} \\
\hline & Female & 28 & Female & 10 & & \\
\hline Age Mean \pm SD & \multicolumn{2}{|c|}{$33.02 \pm 9.23$} & \multicolumn{2}{|c|}{$31.60 \pm 8.74$} & 1.42 & 0.432 \\
\hline Height Mean \pm SD & \multicolumn{2}{|c|}{$158.96 \pm 5.48$} & \multicolumn{2}{|c|}{$160.26 \pm 5.08$} & -1.3 & 0.222 \\
\hline Weight Mean \pm SD & \multicolumn{2}{|c|}{$62.30 \pm 12.06$} & \multicolumn{2}{|c|}{$63.62 \pm 10.61$} & -1.32 & 0.563 \\
\hline
\end{tabular}

\section{Heart Rate}

Pre-induction heart rate (before receiving clonidine or placebo) was $79.6 \pm 5.95$ in group A \& $83.3 \pm 8.73$ in group B with mean difference of -3.78 . This difference was statistically insignificant with $\mathrm{P}$ value of 0.13 as shown in Table 2 \& Figure 1 . After the
II of either sex and age group between 18-45yrs undergoing elective orthopedic, spine, otorhinolaryngologic, gynecological and general surgical procedures under general anesthesia. The study population was subdivided into 2 groups of 50 patients each. Group I (oral Clonidine group) received Tab Clonidine $4 \mu \mathrm{g} /$ $\mathrm{kg}$ orally $60 \mathrm{~min}$ before induction with sips of water. Group II (control group) receive $5 \mathrm{ml}$ distilled water $15 \mathrm{~min}$ before induction. Blood pressure (SBP, DBP, MBP) via NIBP and Heart rate through continuous ECG monitoring recorded by a single observer, preinduction, post induction(pre-laryngoscopy) and at one, two, three and five minutes after laryngoscopy and intubation in both groups. Subsequently every 5 minutes till 30 minutes intraoperatively.

Statistical methods: Analysis was done by descriptive data presented as Mean \pm SD. Pair wise comparison between the groups was done by "T" test. For all tests P value of $<0.05$ will be considered significant.

\section{Result}

The two groups were statistically comparable with respect to age, sex, weight, and American Society of Anaesthesiologists (ASA) physical status as in Table1. administration of drug (clonidine) in Group B and placebo in Group A, Group A showed lot of fluctuations in HR but, HR in Group B was well under control in normal range as per the age. Which was proved but statistical significance of mean differences at various times intervals with $P$ valve less than 0.005 at all intervals as shown in Table 2 \& Figure 1.

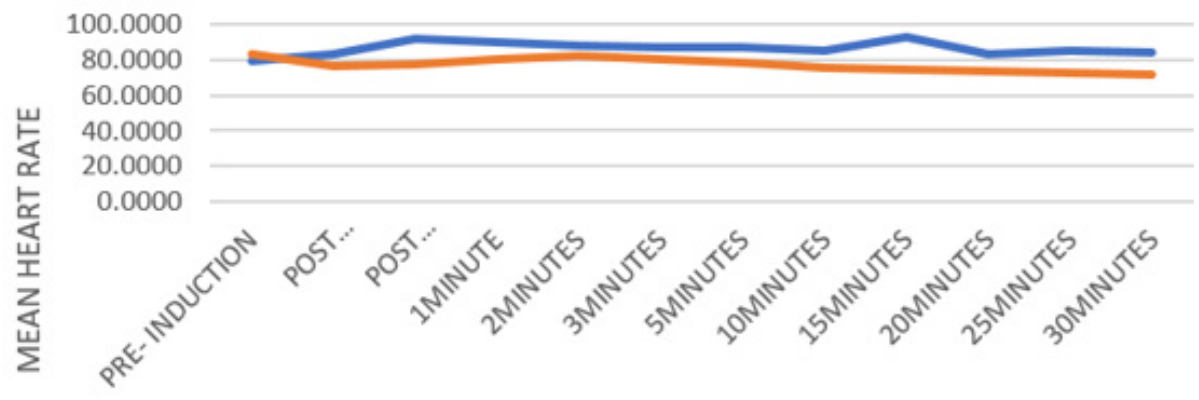

Axis Title

Figure 1: Comparison of Mean Heart rate (HR) between two groups. 
Table 2: Comparison of Mean Heart rate (HR) between two groups.

\begin{tabular}{|c|c|c|c|c|c|c|}
\hline \multirow[t]{2}{*}{ Heart Rate } & \multirow{2}{*}{$\begin{array}{c}\text { Group A } \\
\text { Mean } \pm \text { SD }\end{array}$} & \multirow{2}{*}{$\begin{array}{c}\text { Group B } \\
\text { Mean } \pm \text { SD }\end{array}$} & \multirow{2}{*}{$\begin{array}{l}\text { MEAN DIFFER- } \\
\text { ENCE }\end{array}$} & \multicolumn{2}{|c|}{$\begin{array}{l}\text { 95\% Confidence Interval of } \\
\text { Difference }\end{array}$} & \multirow[t]{2}{*}{$P$ Value } \\
\hline & & & & Lower & Upper & \\
\hline Pre- Induction & $79.6 \pm 5.95$ & $83.3 \pm 8.73$ & -3.78 & -6.75229 & -0.81269 & 0.013 \\
\hline Post Induction (Pre-Laryngescopy) & $83.4 \pm 5.19$ & $76.7 \pm 8.86$ & 6.72 & 3.82852 & 9.60286 & 0.001 \\
\hline $\begin{array}{l}\text { Post Induction Post Laryngescopy } \\
\text { and Intubation }\end{array}$ & $92.22 \pm 9.70$ & $77.14 \pm 6.28$ & 15.08 & 11.82828 & 18.3249 & 0.0008 \\
\hline 1 Minute & $90.14 \pm 8.10$ & $80.16 \pm 8.09$ & 15.08 & 6.76342 & 13.19658 & 0.002 \\
\hline 2 Minutes & $88.46 \pm 7.25$ & $82.46 \pm 7.25$ & 9.98 & 3.12093 & 8.87907 & 0.0004 \\
\hline 3 Minutes & $86.78 \pm 6.79$ & $80.78 \pm 6.79$ & 6 & 3.30302 & 8.69698 & 0.003 \\
\hline 5 Minutes & $86.80 \pm 6.28$ & $77.92 \pm 6.61$ & 6 & 6.31976 & 11.44016 & 0.0008 \\
\hline 10 Minutes & $92.32 \pm 4.92$ & $74.32 \pm 5.78$ & 8.88 & 6.53734 & 11.46266 & 0.0009 \\
\hline 15 Minutes & $84.7 \pm 6.47$ & $75.7 \pm 6.89$ & 9 & 16.04665 & 19.95335 & 0.0002 \\
\hline 20 Minutes & $83.20 \pm 4.54$ & $73.2 \pm 5.43$ & 18 & 8.19451 & 11.80549 & 0.004 \\
\hline 25 Minutes & $85.34 \pm 4.11$ & $72.34 \pm 4.31$ & 13 & 11.36532 & 14.63468 & 0.0008 \\
\hline 30 Minutes & $84.38 \pm 3.10$ & $71.38 \pm 3.10$ & 13 & 11.76586 & 14.23414 & 0.0007 \\
\hline
\end{tabular}

Group A = Controls, Group B = Oral clonidine group

\section{Systolic blood pressure}

Pre- induction difference in systolic blood pressure (SBP) between two groups was 4.56(124.8-120.2) was statistically insignificant ( $p$ value 0.008 ) as shown in Table 3 \& Figure 2. The highest mean SBP $133.26 \pm 00$ ( $\mathrm{mmHg}$ ) belonged to placebo group at post induction, post laryngoscopy and intubation time and the lowest one was at 30mins after drug administration in Group B. Group A showed marked variation in SBP throughout the operative procedures, while Group A under effect of clonidine showed controlled SBP with no patient shooting SBP into hypertensive range. Differences in SBP since from post induction period up to end of time limit of study period were statistically significant with p value of less than 0.005 as shown in data in Table 3 \& Figure 2.

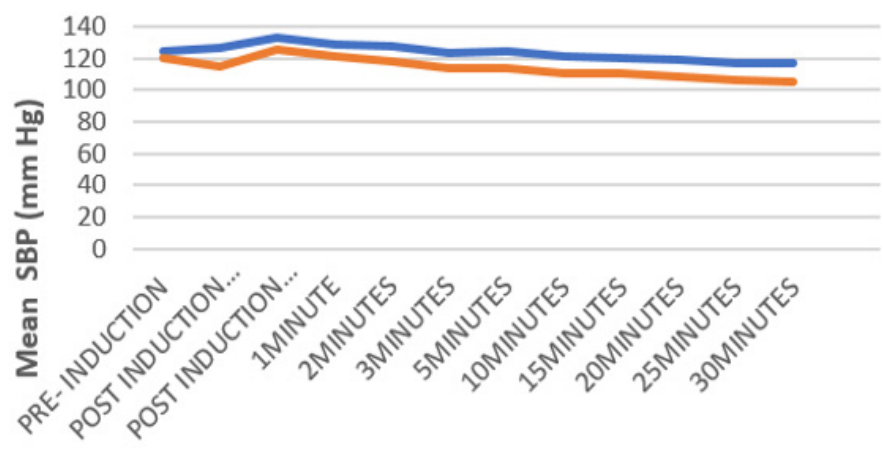

Axis Title

Figure 2: Comparison of Mean Systolic blood pressure (SBP) between two groups

Table 3: Comparison of Mean SBP $(\mathrm{mm} \mathrm{Hg})$ between two groups.

\begin{tabular}{|c|c|c|c|c|c|c|}
\hline \multirow{2}{*}{ Diastolic Blood Pressure } & \multirow{2}{*}{ Group A } & \multirow{2}{*}{ Group B } & \multirow{2}{*}{$\begin{array}{c}\text { Mean Differ- } \\
\text { ence }\end{array}$} & \multicolumn{2}{|c|}{$\begin{array}{c}\text { 95\% Confidence Interval of } \\
\text { Difference }\end{array}$} \\
\cline { 5 - 7 } & Mean \pm SD & Mean \pm SD & & Lower & Upper \\
\hline Pre- Induction & $79.4 \pm 8.17$ & $79.4 \pm 8.17$ & 0 & -3.24624 & 3.24624 & 1 \\
\hline Post Induction (Pre-Laryngescopy) & $82.64 \pm 6.3$ & $70.12 \pm 7.55$ & 12.52 & 9.74459 & 15.29443 & 0.0004 \\
\hline Post Induction Post Laryngescopy and Intubation & $86.62 \pm 8.22$ & $80.04 \pm 9.18$ & 6.58 & 3.11904 & 10.04043 & 0.0017 \\
\hline
\end{tabular}




\begin{tabular}{|c|c|c|c|c|c|c|}
\hline 1 Minute & $81.92 \pm 8.08$ & $75.92 \pm 8.08$ & 6.58 & 2.79278 & 9.20722 & 0.0014 \\
\hline 2 Minutes & $82.56 \pm 8.82$ & $72.56 \pm 8.82$ & 6 & 6.49734 & 13.50266 & 0.0005 \\
\hline 3 Minutes & $82.82 \pm 10.57$ & $72.82 \pm 10.57$ & 10 & 5.80221 & 14.19779 & 0.0012 \\
\hline 5 Minutes & $81.18 \pm 7.43$ & $71.18 \pm 7.64$ & 10 & 7.04763 & 12.95237 & 0.0004 \\
\hline 10 Minutes & $79.42 \pm 6.29$ & $69.42 \pm 7.89$ & 10 & 7.59628 & 12.40372 & 0.0001 \\
\hline 15 Minutes & $81.12 \pm 6.98$ & $71.12 \pm 7.67$ & 10 & 7.50255 & 12.49745 & 0.0002 \\
\hline 20 Minutes & $78.32 \pm 6.24$ & $68.32 \pm 6.34$ & 10 & 7.52278 & 12.47722 & 0.004 \\
\hline 2 Minutes & $79.44 \pm 4.58$ & $68.44 \pm 4.58$ & 11 & 9.18181 & 12.81819 & 0.0028 \\
\hline 30 Minutes & $79.78 \pm 5.07$ & $67.78 \pm 5.07$ & 12 & 9.98692 & 14.01308 & 0.0034 \\
\hline
\end{tabular}

Group A = Controls, Group B = Oral clonidine group

\section{Diastolic blood pressure}

Pre- induction mean difference in systolic blood pressure (DBP) between two groups was nearly zero which was statistically insignificant ( $p$ value 1 ) as shown in Table 4 \& Figure 3. The highest mean DBP $86.62 \pm 8.22$ ( $\mathrm{mmHg}$ ) belonged to placebo group at post induction, post laryngoscopy and intubation time and the lowest one was at 30mins after drug administration in Group B with highest mean difference between two groups of 12.00 ( $\mathrm{mm} \mathrm{hg}$ ). Group A showed marked variation in DBP throughout the operative procedures, while Group A under effect of clonidine showed controlled DBP. Differences in DBP since from post induction period up to end of time limit of study period were statistically significant with $\mathrm{p}$ value of less than 0.005 as shown in data in Table 4 \& Figure 3.

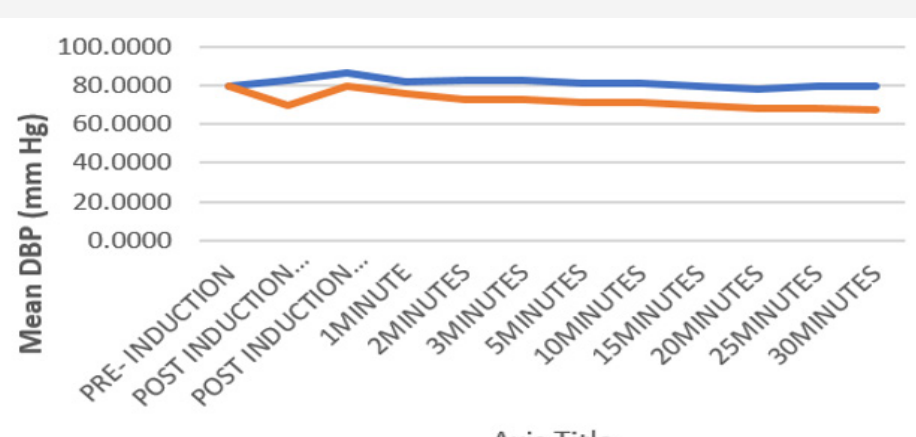

Axis Title

CONTROL/GROUP A ORAL CLONIDINE/GROUP B

Figure 3: Comparison of Mean Diastolic blood pressure (DBP) between two groups.

Table 4: Comparison of Mean DBP $(\mathrm{mm} \mathrm{Hg})$ between two groups.

\begin{tabular}{|c|c|c|c|c|c|c|}
\hline \multirow{2}{*}{ Diastolic Blood Pressure } & \multirow{2}{*}{$\begin{array}{c}\text { Group A } \\
\text { Mean } \pm \text { SD }\end{array}$} & \multirow{2}{*}{$\begin{array}{c}\text { Group B } \\
\text { Mean } \pm \text { SD }\end{array}$} & \multirow{2}{*}{$\begin{array}{l}\text { Mean Differ- } \\
\text { ence }\end{array}$} & \multicolumn{2}{|c|}{$\begin{array}{l}\text { 95\% Confidence Interval of } \\
\text { Difference }\end{array}$} & \multirow{2}{*}{ P Value } \\
\hline & & & & Lower & Upper & \\
\hline Pre- Induction & $79.4 \pm 8.17$ & $79.4 \pm 8.17$ & 0 & -3.24624 & 3.24624 & 1 \\
\hline Post Induction (Pre-Laryngescopy) & $82.64 \pm 6.3$ & $70.12 \pm 7.55$ & 12.52 & 9.74459 & 15.29443 & 0.0004 \\
\hline Post Induction Post Laryngescopy And Intubation & $86.62 \pm 8.22$ & $80.04 \pm 9.18$ & 6.58 & 3.11904 & 10.04043 & 0.0017 \\
\hline 1 Minute & $81.92 \pm 8.08$ & $75.92 \pm 8.08$ & 6.58 & 2.79278 & 9.20722 & 0.0014 \\
\hline 2 Minutes & $82.56 \pm 8.82$ & $72.56 \pm 8.82$ & 6 & 6.49734 & 13.50266 & 0.0005 \\
\hline 3 Minutes & $82.82 \pm 10.57$ & $72.82 \pm 10.57$ & 10 & 5.80221 & 14.19779 & 0.0012 \\
\hline 5 Minutes & $81.18 \pm 7.43$ & $71.18 \pm 7.64$ & 10 & 7.04763 & 12.95237 & 0.0004 \\
\hline 10 Minutes & $79.42 \pm 6.29$ & $69.42 \pm 7.89$ & 10 & 7.59628 & 12.40372 & 0.0001 \\
\hline 15 Minutes & $81.12 \pm 6.98$ & $71.12 \pm 7.67$ & 10 & 7.50255 & 12.49745 & 0.0002 \\
\hline 20 Minutes & $78.32 \pm 6.24$ & $68.32 \pm 6.34$ & 10 & 7.52278 & 12.47722 & 0.004 \\
\hline 25 Minutes & $79.44 \pm 4.58$ & $68.44 \pm 4.58$ & 11 & 9.18181 & 12.81819 & 0.0028 \\
\hline 30 Minutes & $79.78 \pm 5.07$ & $67.78 \pm 5.07$ & 12 & 9.98692 & 14.01308 & 0.0034 \\
\hline
\end{tabular}

Group A = Controls, Group B = Oral clonidine group 


\section{Mean arterial pressure}

Pre- induction difference in mean arterial pressure (MAP) between two groups was 3.833(94.5-90.7) was statistically insignificant ( $p$ value 0.010 ) as shown in Table 5 \& Figure 4. The highest mean MAP (mmHg) 102.16 \pm 7.17 was recorded in placebo group at post induction, post laryngoscopy and intubation time and the lowest one was at 30mins after drug administration in Group B (75.52 $\pm 6.59 \mathrm{mmHg})$. Group A showed marked variation in MAP throughout the operative procedures, while Group A under effect of clonidine showed controlled MAP. Differences in MAP since from post induction period up to end of time limit of study period were statistically significant with $\mathrm{p}$ value of less than 0.005 as shown in data in Table 5 \& Figure 4

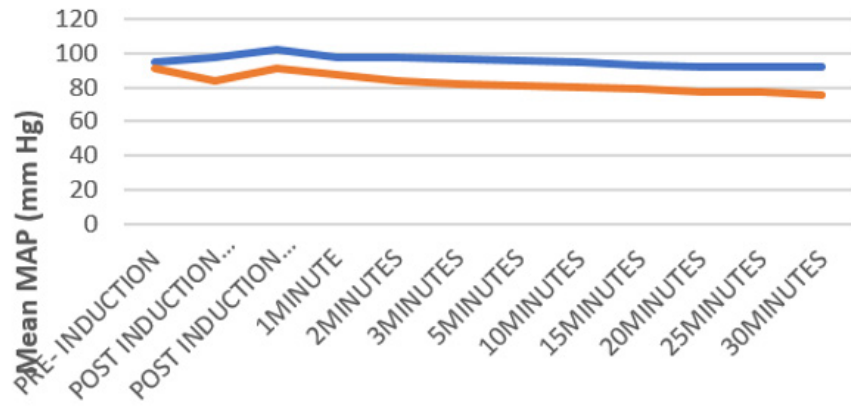

Axis Title

CONTROL/GROUPA

ORAL CLONIDINE/GROUP B

Figure 4: Comparison of Mean Arterial pressure (MAP) between two groups.

Table 5: Comparison of Mean MAP $(\mathrm{mm} \mathrm{Hg})$ between two groups.

\begin{tabular}{|c|c|c|c|c|c|c|}
\hline \multirow[t]{2}{*}{ Mean Arterial Pressure } & \multirow{2}{*}{$\begin{array}{c}\text { Group A } \\
\text { Mean } \pm \text { SD }\end{array}$} & \multirow{2}{*}{$\begin{array}{c}\text { Group B } \\
\text { Mean } \pm \text { SD }\end{array}$} & \multirow{2}{*}{$\begin{array}{l}\text { Mean Differ- } \\
\text { ence }\end{array}$} & \multicolumn{2}{|c|}{$\begin{array}{l}95 \% \text { Confidence Interval of } \\
\text { Difference }\end{array}$} & \multirow[t]{2}{*}{ P Value } \\
\hline & & & & Lower & Upper & \\
\hline PRE- INDUCTION & $94.5 \pm 5.38$ & $90.7 \pm 8.81$ & 3.83333 & 0.92763 & 6.73148 & 0.01 \\
\hline Post Induction (Pre-Laryngescopy) & $97.3 \pm 4.1$ & $83.92 \pm 8.67$ & 13.40667 & 10.68891 & 16.11131 & 0.0013 \\
\hline $\begin{array}{l}\text { Post Induction Post Laryngescopy And Intu- } \\
\text { bation }\end{array}$ & $102.16 \pm 7.17$ & $90.76 \pm 9.00$ & 11.40667 & 8.17439 & 14.63693 & 0.00043 \\
\hline 1 Minute & $97.6 \pm 7.41$ & $87.80 \pm 8.88$ & 11.4 & 6.54971 & 13.04899 & 0.0007 \\
\hline 2 Minutes & $97.66 \pm 7.91$ & $84.12 \pm 9.14$ & 9.8 & 10.14552 & 16.9336 & 0.0003 \\
\hline 3 Minutes & $96.41 \pm 7.68$ & $82.08 \pm 8.71$ & 13.54 & 11.07141 & 17.59462 & 0.0018 \\
\hline 5 Minutes & $95.46 \pm 6.63$ & $81.00 \pm 7.43$ & 14.33 & 11.68994 & 17.22975 & 0.0018 \\
\hline 10 Minutes & $92.96 \pm 5.86$ & $78.68 \pm 6.97$ & 14.46 & 11.99398 & 16.87186 & 0.0004 \\
\hline 15 Minutes & $94.39 \pm 5.71$ & $79.96 \pm 6.56$ & 14.43 & 11.72725 & 16.84513 & 0.0019 \\
\hline 20 Minutes & $91.77 \pm 5.62$ & $77.5000 \pm 8.85$ & 14.28 & 11.77789 & 16.76764 & 0.0009 \\
\hline 25 Minutes & $92.12 \pm 4.97$ & $77.0 \pm 5.78$ & 15.12 & 12.97874 & 17.26066 & 0.0034 \\
\hline 30 Minutes & $92.1 \pm 5.14$ & $75.52 \pm 6.59$ & 16.59 & 14.24562 & 18.93931 & 0.0014 \\
\hline
\end{tabular}

Group A = Controls, Group B = Oral clonidine group

\section{Discussion}

It is a well-established fact that laryngoscopy and endotracheal intubation act as mechanical stimuli to activate a reflex, mediated by the sympathy-adrenal axis and causes significant hemodynamic stress [13-15]. Airway instrumentation leads to stimulation of nerves that carry afferent impulses to the vasomotor centre located in brain stem which in turn activates the sympatho-adrenal system to release catecholamines resulting in increase in the heart rate and blood pressure. There is a significant association between incidence of myocardial infarction and tracheal intubation or extubation [16]. It may also lead to potentially dangerous rise in intracranial and intraocular pressures. Various pharmacologic agents like beta-blockers, lignocaine, calcium channel blockers, ganglion blocking drugs, vasodilators, opioids, and $\alpha 2$-adrenergic agonist have been tried to attenuate this hemodynamic response with varying success.

Clonidine is an imidazoline derivative with selective agonistic action at $\alpha 2$ adrenergic receptors. Its mechanism of action involves stimulation of central $\alpha 2$ adrenergic receptors in the vasomotor center of medulla and presynaptically at the peripheral nerve terminals, blocking release of norepinephrine from the nerve terminals leading to hypotension and bradycardia. It also stimulates 
parasympathetic outflow, increasing vagal tone contributing to the slowing of HR [17]. When given orally, its bioavailability is $100 \%$.

We chose $4 \mathrm{mcg} / \mathrm{kg}$ as the dose of clonidine in accordance with previous studies demonstrating safety with lower incidence of obvious side effects like severe bradycardia and hypotension [18]. Clonidine blunts the reflex tachycardia associated with direct laryngoscopy and tracheal intubation. Carabine et al. [19] suggested that cardiovascular responses by short lasting laryngoscopies can be attenuated with very low doses of oral clonidine. It also decreases the intra operative lability of heart rate.

In Group A (control group), there were wide variation in heart rate during entire operative procedure especially increments in heart rate during laryngoscopy and intubation. But, in Group B (oral clonidine group) heart rate well controlled. These findings corroborated the studies of Roy and Rudra [20], Raval et al. [21] Joshi et al. [22].

There was a slight increase in mean systolic blood pressure (SBP), mean diastolic pressure (DBP) and mean arterial pressure (MAP) at post induction post laryngoscopy and intubation both the groups. In the Clonidine group this rise was not as significant as non-clonidine group. Rest during the entire operative procedure all parameters, mean systolic blood pressure (SBP), mean diastolic pressure (DBP) and mean arterial pressure (MAP) were well controlled in clonidine group and showed marked fluctuations in control group. On analysing these observations, it can be concluded that Clonidine reduces the systolic as well as diastolic blood pressure in operative period. These observations strongly reflect the hypotensive effects of Clonidine and its ability to attenuate rise in SBP during laryngoscopy and intubation. These findings were in agreement with the studies conducted by Das et al. [23] \& Raval et al. [21]. It can be concluded that Clonidine by virtue of its hypotensive effects, systolic more than diastolic, controls the rise in MAP in the study group that was on clonidine premedication. These findings correlate with those of Joshi VS et al. [22] \& Raval et al. [21].

\section{Conclusion}

To conclude oral clonidine at dose of $3 \mathrm{mcg}$ can effectively attenuate the hemodynamic response in operative procedures in adults.

\section{Acknowledgement}

None.

\section{Conflict of Interest}

No Conflict of Interest.

\section{References}

1. Fleisher LA (1994) Peroperative myocardial ischemia and infarction. Int Anaesthesiol Clin 4: 1-15

2. Gill NP, Wright B, Reilly CS (1992) Relationship between hypoxemia and cardiac ischemic events in the peroperative period. Br J Anaesth 68(5): 471-473.
3. Vincent JC (2009) Principles of Anaesthesiology. General and Regional anaesthesia, Vol II Philadelphia: Lea and Fabigee ( $3^{\text {rd }}$ edn): pp. 1212 1223

4. Russell WJ, Morris RG, Frewin DB, Drew SE (1981) changes in plasma catecholamine concentrations during endotracheal intubation. British Journal of Anaesthesia 53(8): 837-839.

5. Black TE, Kay B, Healy TEJ (1984) Reducing the haemodynamic responses to laryngoscopy and intubation. A comparison of Alfentanyl and Fentanyl. Anaesthesia 39(9): 883-887.

6. Wycoff Charles (1960) Endotracheal intubation; effects on blood pressure and pulse rate. Anaesthesiology. 21(2): 153-157.

7. Dipak LR, Malini KM (2002) Oral clonidine premedication for attenuation of haemodynamic response to laryngoscopy and intubation. Ind J Anaesth 46(2): 124-129.

8. Wright PM, Carabine UA, McClune S, Orr DA, Moore J (1990) Preanaesthetic medication with Clonidine. Br J Anaesth 65(5): 628-632.

9. Charles E Laurito, Verna L Baughman, Gerald L Becker, Francesca Cunningham, Bernard H Pygon (1993) Oral Clonidine blunts the haemodynamic responses to brief but not prolonged laryngoscopy. J Clin Anaesth 5(1): 54-57.

10. Giles TD, Thomas MC, Quirol A, Rice JC, Plauche W, et al. (1987) Acute and short-term effects of Clonidine in heart failure. Angiology 38(7): 5348.

11. Hermiller JB, Magorien RD, Leithe ME, Unverferth DV, Leier CV (1983) Clonidine in congestive heart failure: a vasodilator with negative inotropic effects. Am J Cardiol 51(5): 791-795.

12. Chadha R, Padmanabhan V, Joseph A, Mohandas K (1992) Oral Clonidine pretreatment for haemodynamic stability during craniotomy. Anaesthesia Intensive Care 20(3): 341-344.

13. King BD, Harris LC Jr, Greifenstein FE, Elder JD Jr, Dripps RD (1951) Reflex circulatory responses to direct laryngoscopy and tracheal intubation performed during general anaesthesia. Anaesthesiology 12(5): 556-566.

14. Devault M, Greifenstein FE, Harris LC (1960) Circulatory responses to endotracheal intubation in light general anesthesia-the effect of atropine and phentolamine. Anesthesiology 21: 360-362.

15. Prys Roberts C, Greene LT, Meloche R, Foëx P (1971) Studies of anaesthesia in relation to hypertension II. Hemodynamic consequences of induction and endotracheal intubation. Br J Anaesth 43: 531-547.

16. Chandrashekhar PM, King R (1984) Attenuation of cardiovascular response to endotracheal intubation. Indian J Anaesth 32: 358-365.

17. Satoskar RS, Bhandarkar SD, Ainapure SS (2002) Pharmacology and Pharmacotherapeutics ( $17^{\text {th }}$ edn), Mumbai: Bombay Popular Prakashan, India, p. 1111

18. Carabine UA, Wright PM, Moore J (1991) Preanaesthetic medication with clonidine: A dose-response study. Br J Anaesth 67(1): 79-83.

19. Carabine UA, Wright PM, Howe JP, Moore J (1991) Partial attenuation of the pressor response to intubation by clonidine. Anaesthesia 469: 613-707.

20. Roy S, Rudra A, Gupta K, Mondal T, Chakravorty S (1993) Attenuation of cardiovascular responses to laryngoscopy and tracheal intubation with oral clonidine (arkamine). Indian J Anaesth 41: 62-65.

21. Raval DL, Mehta MK (2002) Oral clonidine pre-medication for attenuation of hemodynamic response to laryngoscopy and intubation. Indian J Anaesth 46(2): 124-129.

22. Joshi VS, Vyavhare RD, Jamadar NP, Patil BM, Shiledar V (2012) Attenuation of cardiovascular responses to laryngoscopy and endotracheal intubation: Comparative evaluation of clonidine and lignocaine. Indian J Basic Appl Med Res 1(4): 313-323.

23. Das AK, Rudra R (1995) Clinical efficacy of oral clonidine as preanaesthetic medicant. Indian J Anaesth 43:133-139. 